\title{
A long-term multi-proxy record of varved sediments suggests climate-induced mixing-regime shift in a large hard-water lake $\sim 5000$ years ago
}

\author{
Walter FINSINGER,${ }^{1,2^{*}}$ Thierry FONVILLE, ${ }^{\circ}$ Emiliya KIRILOVA,,${ }^{1}$ Andrea LAMI,${ }^{3}$ Piero GUILIZZONI, ${ }^{3}$ \\ André F. LOTTER ${ }^{1}$
}

${ }^{1}$ Palaeoecology, Department of Physical Geography, University of Utrecht, Laboratory of Palaeobotany and Palynology, Budapestlaan 4, NL-3584 CD Utrecht, The Netherlands; ${ }^{2}$ Centre for Bio-Archaeology and Ecology (UMR 5059 CNRS/UM2/EPHE), 163 Rue A. Broussonnet, F-34090 Montpellier, France; ${ }^{3}$ Institute for Ecosystem Study (CNR-ISE), Largo Tonolli 50, I-28922 Verbania Pallanza, Italy *Corresponding author: walter.finsinger@univ-montp2.fr

WS, TF, joint first authorship.

${ }^{\circ}$ Current address: Palaeoenvironmental Laboratory of the University of Southampton (PLUS), Geography and Environment, University of Southampton Highfield, Southampton SO17 1BJ, UK

\begin{abstract}
The long-term terrestrial and aquatic ecosystem dynamics spanning between approximately 6200 and 4800 cal BP were investigated using pollen, diatoms, pigments, charcoal, and geochemistry from varved sediments collected in a large stratified perialpine lake, Lago Grande di Avigliana, in the Italian Alps. Marked changes were detected in diatom and pigment assemblages and in sediment composition at 4900 cal BP. Organic matter rapidly increased and diatom assemblages shifted from oligotrophic to oligo-mesotrophic planktonic assemblages suggesting that nutrients increased at that time. Because land cover, erosion, and fire frequency did not change significantly, external nutrient sources were possibly not essential in controlling the lake-ecosystem dynamics. This is also supported by redundancy analysis, which showed that variables explaining significant amounts of variance in the diatom data were not the ones related to changes in the catchment. Instead, the broad coincidence between the phytoplankton dynamics and rising lake-levels, cooler temperatures, and stronger spring winds in the northern Mediterranean borderlands possibly points to the effects of climate change on the nutrient recycling in the lake by means of the control that climate can exert on mixing depth. We hypothesize that the increased P-release rates and higher organic-matter accumulation rates, proceeded by enhanced precipitation of iron sulphides, were possibly caused by deeper and stronger mixing leading to enhanced input of nutrients from the anoxic hypolimnion into the epilimnion. Although we cannot completely rule out the influence of minor land-cover changes due to human activities, it may be hypothesized that climate-induced cumulative effects related to mixing regime and P-recycling from sediments influenced the aquatic-ecosystem dynamics.
\end{abstract}

Key words: Varves, pigments, pollen, diatoms, $\mu X R F$, stratification, climate change, Europe.

Received: November 2013. Accepted: February 2014.

\section{INTRODUCTION}

Ecosystems can change rapidly in response to disturbances and theory suggests that such shifts can be attributed to alternative stable states (Scheffer and Carpenter, 2003). Past and present human activities are well known to be drivers of such shifts (Bradshaw et al., 2005; Dearing, 2008) and the likelihood of reaching ecological thresholds may increase when humans reduce resilience (Folke et al., 2004). However, there are several ecological thresholds that may be reached in the absence of humans (Willis et al., 2010), indicating that factors other than human activities (e.g., climatic changes, volcanic eruptions) may play an important role in determining ecosystem dynamics. The long-term dynamics, feedbacks, and processes influencing trophic changes in temperate lakes are areas of active research. Lakes in remote regions have been comparatively less affected by direct human activities in the past (Smol et al., 2005; Battarbee and Bennion,
2011). By contrast, in urban, industrial, and agricultural settings, the higher abundance of nutrient sources (municipal and industrial discharges, and runoff from agricultural or urban lands) has often driven cultural eutrophication in historical times (Lotter and Birks, 1997; Smol, 2008). In such lowland anthropogenically impacted lakes, cultural eutrophication often masks the influence of other factors and hampers an assessment of the full ecosystem response to natural environmental change (Battarbee and Bennion, 2011). In addition, trophic shifts do not occur frequently and standard ecological methods, such as experiments and small-scale observations, may not be applicable to study such large, infrequent phenomena (Genkai-Kato, 2007). Paleolimnological indicators of environmental changes (proxies) may instead help to investigate the speed and nature of ecosystem responses in conditions when human activities were not significantly affecting the environment. Evidences from such long-term records suggest that climatic changes can determine the emergence of ecosystem 
shifts in thermally stratified lakes. Still, the mechanisms acting during such climate-induced shifts (and essentially increasing phosphorus concentrations in the photic zone, thus enhancing phytoplankton biomass) are not well understood or constrained. Whereas some studies highlighted the role of nutrient inputs from external nutrient sources (essentially from erosion of nutrient-rich soils) (Brauer et al., 1999; Schmidt et al., 2002), others pointed out that changes of mixing regime or of mixing depth may be important in changing nutrient concentrations in the photic zone from internal sources (Smol and Boucherle, 1985; Moser et al., 2002; Smol et al., 2005; Kirilova et al., 2009). However, most of these long-term records refer to shifts in response to high-amplitude climatic changes with associated large land-cover changes that occurred at the transition between the late glacial and the Holocene. Instead, responses to lower-amplitude Holocene climate variability are receiving greater attention in recent years (MartinPuertas et al., 2012).

In this study, we analysed a short lake-sediment section that showed a conspicuous diatom-assemblage shift at about 4900 cal BP, i.e., before the onset of intensive agriculture and land use in the region (Tinner et al., 1999; Finsinger and Tinner, 2006). The lake is a stratified hard-water lake that contains varved sediments (Finsinger et al., 2006), attesting to the fact that the lake is predisposed for strong stratification due to its morphometry and wind shielded location. It thereby provides the opportunity to investigate the dynamics (speed and nature) of change in the aquatic ecosystem in response to environmental changes at high temporal resolution (here a sample spans 15 years). We used pollen and charcoal to estimate changes in the terrestrial ecosystem (vegetation changes and fire occurrence), diatoms and pigments to characterize changes in the aquatic ecosystem (phytoplankton assemblages, occurrence of cyanobacteria and anaerobic sulphur bacteria), and geochemical analyses of the sediments to estimate runoff and to trace redox changes at the sediment-water interface. This multi-proxy approach may allow the reconstruction of environmental changes integrating both changes in the terrestrial and aquatic ecosystems.

\section{METHODS}

\section{Site description}

Lago Grande di Avigliana (353 m asl; 4503' 54 'N, $\left.07^{\circ} 23^{\prime} 12^{\prime \prime} \mathrm{E}\right)$ is a $\sim 0.8 \mathrm{~km}^{2}$ large, $26 \mathrm{~m}$ deep hypertrophic hard-water lake that is part of a complex hydrological chain of four lake basins (Fig. 1), the two outer ones being overgrown (Finsinger and Tinner, 2006). It is located at the southwestern edge of the European Alps in a windshielded position. The lake is believed to have been amongst the most eutrophic lakes in Italy ( $\mathrm{n}=147$ lakes, Tartari et al., 2004). Recent conservation measures, which included the deflection of sewage discharge, had a positive effect on the lake's water quality (Finsinger et al., 2006). Lago Grande di Avigliana is at present monomictic. Full circulation occurs only in late winter-early spring (February-March) and the hypolimnion is partially reoxygenated; for example, in March 2002 oxygen saturation at the lake's deepest point reached $3.5 \mathrm{mg} \mathrm{L}^{-1}$. Hypoxia then increased progressively during thermal stratification, reaching concentrations below $0.2 \mathrm{mg} \mathrm{L}^{-1}$ at the deepest point of the lake between April-May and December (www.arpa.piemonte.it/). At present, internal loading is at least partly responsible for maintaining high nutrient concentrations in Lago Grande di Avigliana. When spring circulation occurs, nutrients that accumulated in the anoxic hypolimnion during stagnation are mixed into the photic zone. Current spring TP and $\mathrm{pH}$ levels in the epi- and monimolimnion are 56 and $90 \mu \mathrm{g} \mathrm{L}^{-1}$ and 8.2 and 7.7, respectively. Highest TP concentrations occur near the sediment-water interface in summer (up to $800 \mu \mathrm{g} \mathrm{L}^{-1}$ ). In late summer, cyanobacterial blooms often occur, which then dominate the total phytoplankton assemblages ( $A n$ abaena affinis reached abundance of $\sim 85 \%$ in AD 1980) (de Bernardi et al., 1984). Climate is temperate without a dry season and precipitation is about $800 \mathrm{~mm}$ year ${ }^{-1}$ with maxima occurring in spring and autumn. The catchment vegetation is dominated by deciduous temperate trees (Finsinger and Tinner, 2006).

\section{Field and laboratory methods}

Two sets of parallel sediment cores were obtained with a piston corer operated from a floating platform (UWITEC) in the central part of the basin (water depth: $\sim 25 \mathrm{~m}$; Fig. 1). The core drives ( $3 \mathrm{~m}$ length, $5.7 \mathrm{~cm}$ in diameter) were cut into $1 \mathrm{~m}$ long segments, transported to the lab, cut longitudinally, photographed, and stored at $\sim 4^{\circ} \mathrm{C}$. Core segments were visually correlated to each other to build a composite sediment record and particular attention was given to the correlation between segments that were analysed in this study. The inorganic element composition of the sediments in these segments was determined on unprepared core halves using an ITRAX $\mu \mathrm{X}$-ray fluorescence ( $\mu \mathrm{XRF}$ ) core scanner (Croudace et al., 2006). The $\mu \mathrm{XRF}$ records are displayed as counts per second (cps). Colour images of the core halves were transformed to greyscale images and a greyscale profile was plotted with the ImageJ v1.41o software (http://rsbweb.nih.gov/ij/).

Since sediments mostly consist of carbonate-rich, finely annually laminated gyttja (Lotter, 1989; Fig. 2 A-C), a floating chronology was established for the sediments in two segments based on repeated counts of biogenic varves according to Lotter and Lemcke (1999). The light/dark couplets were counted in increments of $5 \mathrm{~mm}$ under a stereomicroscope at $15 \times$ magnification and a composite record was developed by synchronization of distinct 
marker beds and using $\mu \mathrm{XRF}$ records. The conspicuous sediment-colour change (Fig. 2) broadly coincides with the onset of the Fagus expansion, which is correlated to the transition between pollen zones AVP-9 to AVP-10 in the nearby Lago Piccolo di Avigliana pollen record (Finsinger and Tinner 2006). Based on the depth-age model in that record, the age of the sediment-colour transition in LGA is estimated at $\sim 4915 \pm 200 \mathrm{cal}$ yrs BP. The sediments of two segments were first cut into contiguous 15 -year slices and thereafter subsampled cutting polygons of $1 \mathrm{~cm}^{2}$ surface from each slice (Segerström and Renberg, 1986), freeze-dried and processed for diatoms, pollen, macrocharcoal, loss-on-ignition (LOI), and carbon-nitrogen ratio (C:N) analyses. A distinct ( $>2 \mathrm{~cm}$ thick) turbidite in core AG10 (Layer C, Fig. 2) was excluded from the analyses. Sediments from segment AG002-III were sampled for pigment and LOI analyses, and thereafter used to prepare sediment-thin sections according to Lotter and Lemcke (1999). For diatom analyses, samples were treated with $\mathrm{H}_{2} \mathrm{O}_{2}$ and $\mathrm{HCl}$, and $\mathrm{Naphrax}^{\circledR}$ was used as mounting medium. At least 300 valves were counted at $1000 \times$ magnifications to determine their relative abundance (\% diatom sum). Diatom concentrations were calculated based on the sedimentation-tray technique (Battarbee, 1973). Diatom taxonomy followed Krammer and Lange-Bertalot (Krammer and Lange-Bertalot, 1999a, 1999b, 2000, 2004). Pollen samples were prepared following standard methods (Finsinger et al., 2006), stained, and mounted on microscopic slides. At least 300 grains have been identified and counted in each sample at $\times 400$ magnifications. Pollen percentages were grouped as arboreal, shrub, and herb taxa, and a subgroup of the latter were summarized as anthropogenic-indicator taxa following Behre (1981). Exotic marker grains (Lycopodium) were added to the samples to allow the calculation of pollen concentrations (Stockmarr, 1971). For the macrocharcoal analysis, samples were treated with $\mathrm{NaOCl}$ and $\mathrm{NaOH}$, sieved under a gentle water jet, and charcoal particles $>160 \mu \mathrm{m}$ were enumerated under a stereomicroscope at $\times 40$ magnification, following Genries et al. (2012).

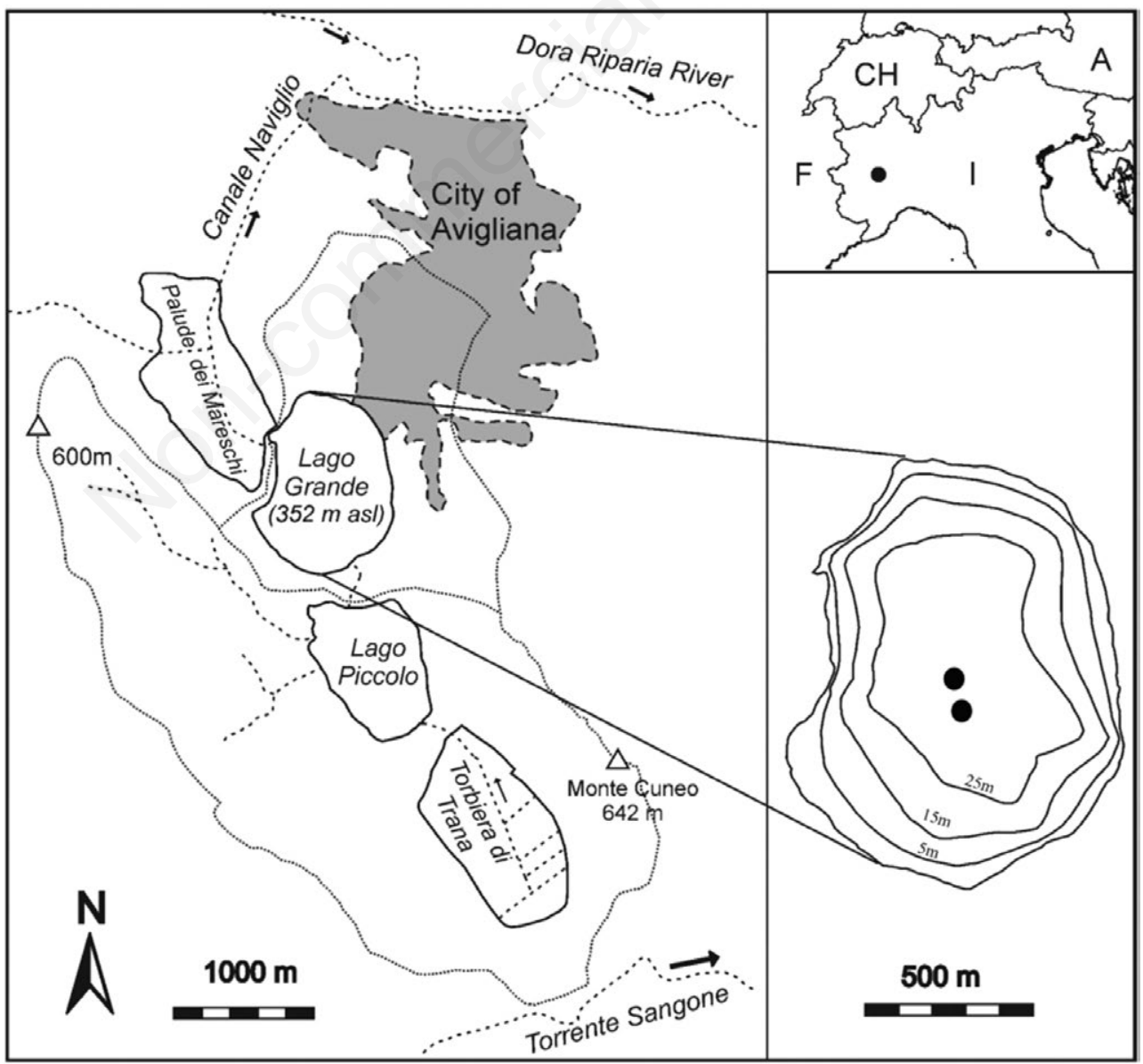

Fig. 1. Maps with surface hydrology in the Avigliana region (left), lake bathymetry and coring locations (full circles) (right). Modified from Finsinger et al., 2006. 
LOI was measured following Heiri et al. (2001) to estimate the amount of organic matter, the carbonate content, and the ignition residue (mostly containing clastic material and biogenic silica). To measure $\mathrm{C}: \mathrm{N}$ ratios, organic carbon $(\mathrm{C})$ and total nitrogen $(\mathrm{N})$ were measured with an EA1110 element analyzer (CE Instruments, UK). For pigments, a volume of $1 \mathrm{~cm}^{3}$ of sediment was taken and stored at $-20^{\circ} \mathrm{C}$ before processing. Specific algal and bacterial pigments were measured as nanomoles per gram of organic matter (nmol $\mathrm{g}_{\mathrm{LOI}}{ }^{-1}$ ) by ion pairing, reverse-phase HPLC (Mantoura and Llewellyn, 1983; Lami et al., 2000).

\section{Numerical analyses}

Statistically significant zone boundaries in the diatom and pollen datasets were determined using constrained hierarchical clustering of a distance matrix, with clusters constrained by sample order, and comparing the dispersion of the hierarchical classification to that obtained from a broken stick model (Bennett, 1996) with the rioja package (Juggins, 2012).

To estimate biomass-burning rates, the charcoal record was decomposed into charcoal peaks $\left(\mathrm{C}_{\text {peaks }}\right)$ and back- ground $\left(\mathrm{C}_{\text {back }}\right)$ components. As indicated by several lines of evidence, $\mathrm{C}_{\text {peaks }}$ represent local large fires that affected a great part of the catchment, whereas the $\mathrm{C}_{\text {back }}$ component rather reflects area burned within the entire charcoalsource area ( $>10 \mathrm{~km}$ radius) (Higuera et al., 2007). The macrocharcoal record was analysed with CharAnalysis v1.0 (Higuera et al., 2009). To summarize the main patterns in the diatom, pollen, pigments, and $\mu \mathrm{XRF}$ datasets, we used indirect-gradient ordination. Both pollen and diatom datasets have short gradient lengths ( 0.8 and 2.1 , respectively) as estimated using Detrended Correspondence Analysis (DCA), suggesting the use of linear-based ordination methods such as Principal Components Analysis (PCA). PCAs of the diatom and pollen datasets were based on a covariance matrix (ordinary PCA), whereas for the pigment and $\mu \mathrm{XRF}$ datasets PCAs were based on a correlation matrix (standardized PCA). The main signal captured by the PCA analyses was summarized plotting the samples scores on PCA axis 1 in the stratigraphic plots (Fig. 3). Direct-gradient ordination by redundancy analysis (RDA) was conducted to determine which linear combination of explanatory variables best explain patterns in

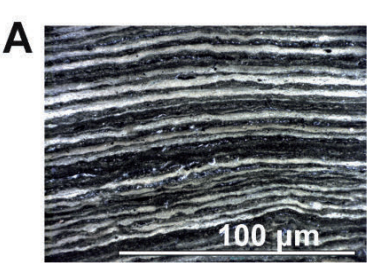

B

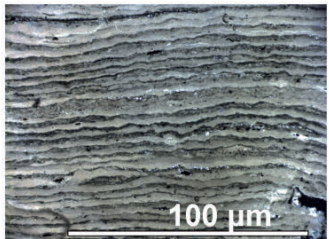

AG04
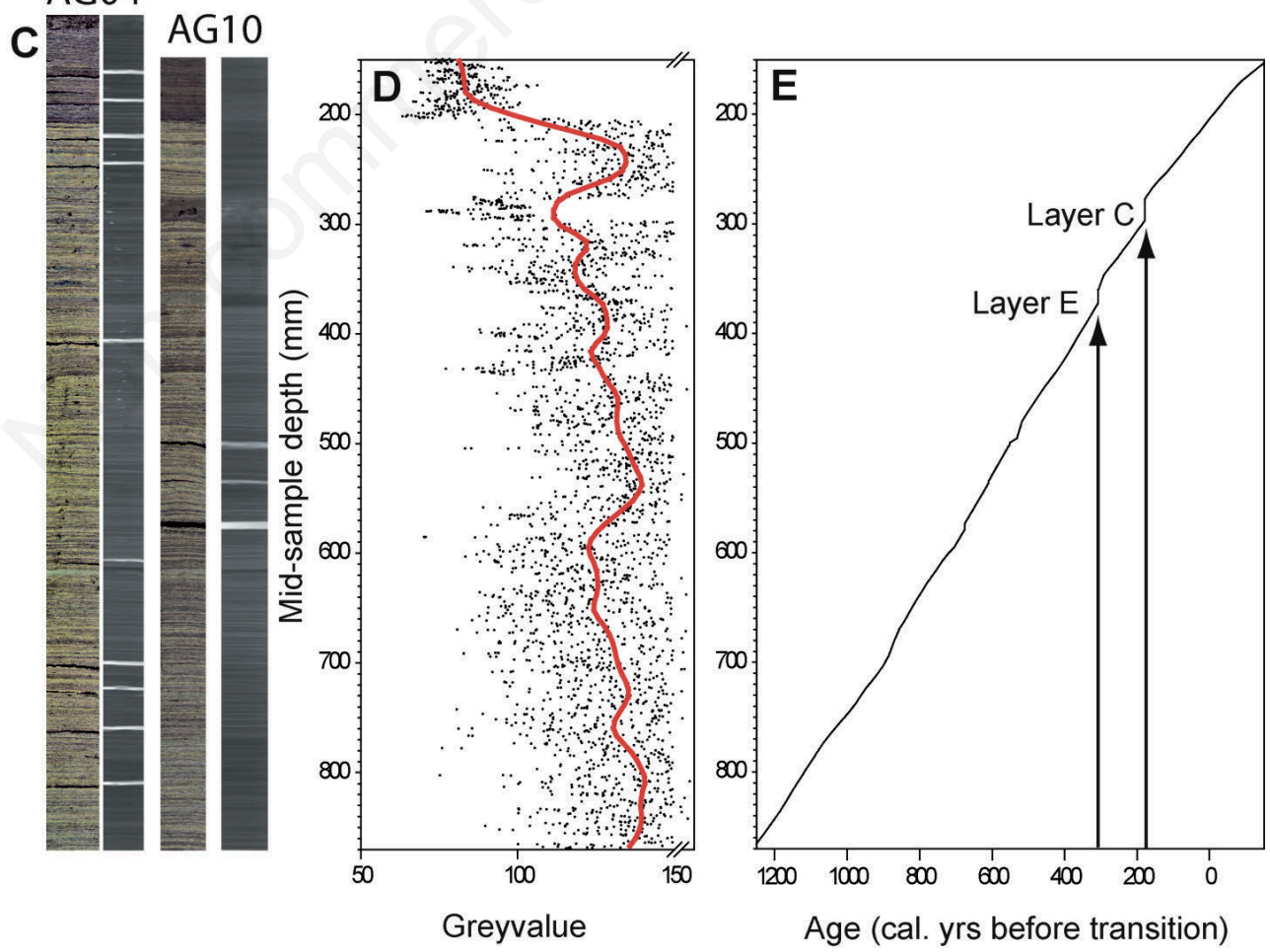

Fig. 2. Images of the sediment (A-C), greyscale record (D), and (E) depth-age relationship based on varve counts. A, B) Enlarged microscopic images of thin sections under polarized light. C) Images of split-core halves and X-ray radiographs for the two cores. D) The greyscale record is plotted only for sediment segment AG10-II (high values=light sediment colour, low values=dark sediment colour) and is smoothed with loess [ $\sim 100$ yrs smoothing window (using 250 data points)]; sediment voids, marked as white bands in the X-ray radiographs, were deleted before smoothing the greyscale record. 
diatom assemblages. The explanatory variables included selected fossil pigments, pollen PCA axis 1 sample scores, selected $\mu \mathrm{XRF}$ records, and charcoal-accumulation rates. RDA was performed with forward selection of explanatory variables and Monte Carlo permutation test (with 999 unrestricted permutations) to determine a subset of variables that explained significant $(\mathrm{P}<0.05$ with a Bonferroni-type adjustment for significance level; Lotter et al., 1997a) and independent amounts of variation in the diatom data. For this purpose, the pigment and $\mu \mathrm{XRF}$ datasets were first linearly interpolated to annual resolution and then averaged (moving average; window width $=15$ years) in order to obtain data matrices with the same sampling resolution as the diatom, pollen, and macrocharcoal records. All ordinations were run with Canoco v4.52 (ter Braak and Šmilauer, 2003) with square-root transformed percentage data for diatom and pollen.

Cross-correlation analyses were performed with MyStat v12 (Systat Software Inc., Chicago, USA) using pollen percentages and unsmoothed charcoal-accumulation rates to investigate the effects of biomass-burning rates on vegetation composition.

\section{RESULTS}

\section{Inorganic sediment composition}

Sediment colour became darker at $\sim 4900$ cal BP (Fig. 2 A-D) and thin-section analyses indicate that spring/summer (light calcite rich) layers became thinner and autumn/winter (dark organic) layers became thicker
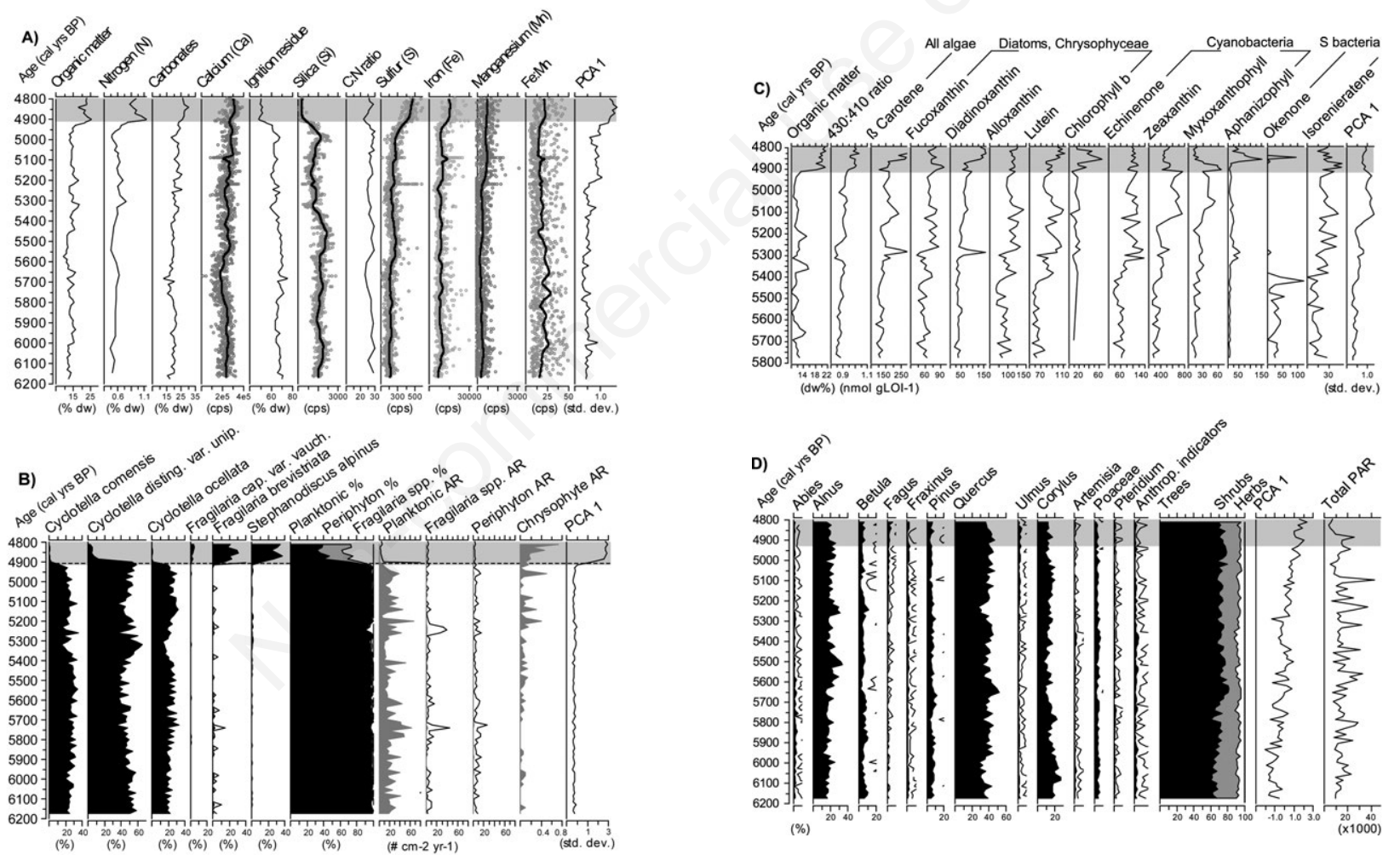

Fig. 3. A) Changes in inorganic sediment composition (core AG10-II). Loss-on-ignition (LOI) (organic matter, carbonates, and ignition residue $)$ as $\%$ dry weight $(\% \mathrm{dw})$ and as accumulation rates $\left(\mathrm{g} \mathrm{cm}^{-2} \mathrm{yr}^{-1}\right)$, Nitrogen $(\% \mathrm{dw})$, atomic C:N ratio, $\mu$ XRF records $(\mathrm{Calcium}$ (Ca), Silica (Si), Sulphur (S), Iron (Fe), and Iron:Manganese ratio (Fe:Mn) as counts per seconds (cps); empty circles: datapoints; thick line: loess smoothed records ( $\sim 100 \mathrm{yr}$ smoothing window), and sample scores of PCA axis 1; since the distribution of Fe, Mn, and $\mathrm{Fe}: \mathrm{Mn}$ ratio records were strongly left-skewed, their $\mathrm{x}$-axes were cut in order to show the variations of the smoothened records. B) High-resolution diatom record (selected diatom taxa as \% values (black silhouettes), accumulation rates $\left(\times 10^{6}\right)$ of diatom groups and Chrysophyte cysts, and sample scores of PCA axis 1; horizontal shaded area: darker sediments; dashed horizontal line: statistically significant zone boundary. C) Fossil pigment record [selected pigments only; abundances expressed as nanomoles per gram of organic matter (nmol $\left.\mathrm{L}_{\mathrm{LOI}}{ }^{-1}\right)$ ] along with organic matter (as \% dry weight $(\% \mathrm{dw})$ ), and sample scores of the first PCA axis. D) High-resolution pollen record (as percentages; selected pollen taxa only), selected pollen sums (the Anthropogenic Indicators curve includes following taxa: Artemisia, Cerealia, Melampyrum, Plantago, and Urticaceae), sample scores of the first PCA axis, and total pollen accumulation rates (PAR). Horizontal shaded area: darker sediments. 
(Fig. $2 \mathrm{~A}-\mathrm{B}$ ). In keeping with this, the LOI-derived estimate of organic matter increased at $\sim 4900 \mathrm{cal} \mathrm{BP}$ (Fig. 3a). The other two LOI-derived estimates of sediment composition [calcium $(\mathrm{Ca})$ and ignition residue] are in good agreement with $\mu \mathrm{XRF}$ records of $\mathrm{Ca}$ and silica $(\mathrm{Si})$. C:N ratio values were $>20$ throughout, pointing to a dominant and continuous input of terrestrial organic matter into the lake (Meyers, 1994). The PCA1 sample scores indicate that the sediment composition changed first at $\sim 5250-5200 \mathrm{cal} \mathrm{BP}$ and later at $\sim 4900 \mathrm{cal} \mathrm{BP}$. Whereas the first change only involved a slight increase of iron $(\mathrm{Fe})$ and manganese $(\mathrm{Mn})$, the second change was characterized by a more distinct increase of sulphur (S) and $\mathrm{Fe}$ and by a drastic decrease of $\mathrm{Si}$ (see also PCA biplot; Supplementary Material). The Titanium (Ti) record (Fig. 4) is characterized by a high variability and the occurrence of several peaks that may be indicative of stronger short-term erosion events. Overall, Ti concentrations were highest at about $6100 \mathrm{cal} \mathrm{BP}$, gradually decreased until about $5400 \mathrm{cal} \mathrm{BP}$ and thereafter slightly

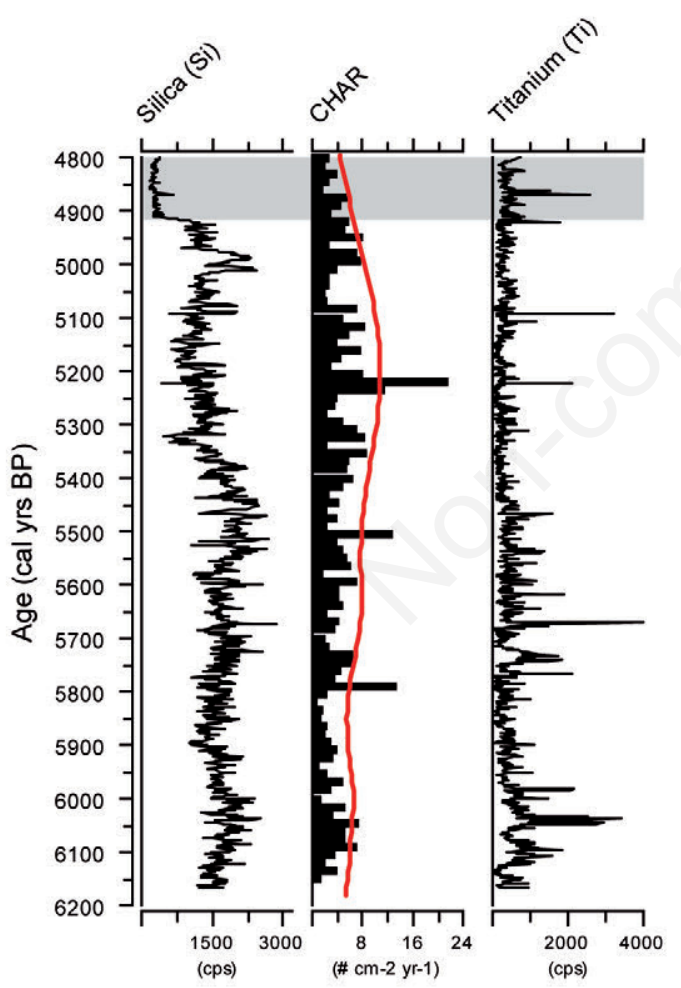

Fig. 4. Comparison between macrocharcoal-inferred fire history and the $\mu \mathrm{XRF}$-derived titanium (Ti) record (as counts per second (cps)) as proxy for runoff from the catchment. The charcoal record was decomposed into the charcoal background $\left(\mathrm{C}_{\mathrm{back}}\right)$ component and the $\mathrm{C}_{\text {peaks }}$ component [peaks exceeding the $\mathrm{C}_{\text {back }}+\mathrm{C}_{\text {threshold }}$ values (red line)], which is indicative for local large biomass-burning episodes. Horizontal shaded area: darker sediments. increased. Titanium is strongly correlated with PCA axis 2 (Supplementary Material) suggesting that its changes were independent of the other inorganic elements.

\section{Diatom assemblages}

Diatom preservation was overall good and no dissolution features were observed. PCA1 sample scores and the only statistically significant zone boundary indicate that diatom assemblages (Fig. 3B) from sediments before $\sim 4900$ cal BP were markedly different from assemblages deposited later. Assemblages changed from being dominated by planktonic taxa (Cyclotella (Kützing) Brébisson) to assemblages characterized by higher abundances of Fragilaria Lyngbye, periphytic diatoms, and Stephanodiscus alpinus Hustedt. Planktonic diatom-accumulation rates decreased abruptly at $\sim 4900 \mathrm{cal} \mathrm{BP}$, suggesting that their productivity in the lake rapidly decreased. The diatom-accumulation rate drop suggests that the Si concentration decrease can be referred to a decrease in biogenic silica. In parallel to the planktonic diatom-accumulation rates decrease, Chrysophyte-cysts accumulation rates increased after $4900 \mathrm{cal} \mathrm{BP}$. The higher abundance of Fragilaria spp. at $\sim 5250 \mathrm{cal} \mathrm{BP}$ is related to turbidite layer $\mathrm{E}$.

\section{Fossil pigments}

Pigment preservation was overall good with $430 \mathrm{~nm}: 410 \mathrm{~nm}$ ratios $>0.85$ (Guilizzoni et al., 1992). The continuous presence of Isorenieratene (produced by green sulphur bacteria) indicates that anoxic conditions reached (at least seasonally) the photic zone throughout. The filamentous cyanobacteria Anabaena (as inferred from the carotenoid Aphanizophyll), which dominate the phytoplankton in autumn in this lake (de Bernardi et al., 1984), were a significant component of the algal community already before human activities altered the ecosystem in the past century. PCA axis 1 captured a gradient that is mainly related to the abundance of Okenone (Fig. 3C and S6 in ESM), pigments produced by obligate anaerobic photosynthetic purple sulphur bacteria (Chromatiaceae). Sample scores in the PCA biplot of the pigment dataset showed greater overlap than in PCAs of the diatom and of the inorganic-sediment component datasets. Nevertheless, PCA1 sample scores indicate that pigment assemblages changed mostly at $\sim 5150$ cal BP when pigments from cyanobacteria (Zeaxanthin, and Myxoxanthophyll) increased. A smaller change can be detected at about 5400 cal BP when pigments from green algae (Lutein, Alloxanthin) and from cyanobacteria (Echinenone, Zeaxanthin) increased suggesting enhanced productivity.

\section{Vegetation and fire dynamics}

No statistically significant zone boundaries were detected attesting to the fact that pollen assemblages 
changed little from 6200 to 4800 cal BP (Fig. 3D). As in other parts of the southern Alpine region, vegetation was dominated by mixed deciduous-oak forests throughout (Tinner et al., 1999; Valsecchi et al., 2008). The very low abundance and the discontinuous presence of anthropogenic-indicator pollen (i.e., Cerealia-type, Plantago, Melampyrum, and Urticaceae) may indicate the presence of small and/or discontinuous local settlements and agricultural activities in the vicinity of the lake. However, herb and anthropogenic-indicator pollen abundance were low and these pollen types also include species that were native in the regional flora before human activities changed the landscape substantially. As shown by the PCA1 sample scores, forest-cover composition changed gradually. As inferred from rising pollen percentage values of Fagus, the changes were mainly related to the population expansion (Supplementary Material) of this drought-sensitive deciduous tree (Jump et al., 2006). Pollen percentage values of Fagus pollen attained $~ 7 \%$ in the topmost sample, a value that is close to the maximum relative abundance attained in the pollen record from Lago Piccolo di Avigliana (Finsinger and Tinner, 2006).

The low-frequency variation of $\mathrm{C}_{\text {back }}$ (Fig. 4) indicates that regional area burnt was lower during the period 6150$5700 \mathrm{cal}$ BP than from 5700 to $5000 \mathrm{cal} \mathrm{BP}$. At $\sim 5000 \mathrm{cal}$ $\mathrm{BP}$, regional area burnt decreased and reached similar magnitude as at around $6000 \mathrm{cal} \mathrm{BP}$.

\section{Influence of fires on runoff and on vegetation}

As the ignition-residue record seems to be largely influenced by biogenic silica (Fig. 3 A,B) we used the $\mu$ XRF-derived Ti (Fig. 4) as independent proxy for erosion. Three major peaks (dated to ca. 5760, 5480, and 5200 cal BP) emerged after the decomposition of the macrocharcoal record, with minor peaks detected at ca. 5950 and $4830 \mathrm{cal} \mathrm{BP}$. Whereas several $\mathrm{C}_{\text {peaks }}$ were often located close to Ti peaks (at $\sim 6050, \sim 5750, \sim 5500$, and $\sim 5200$ cal BP), suggesting an influence of local large fire events on catchment runoff, other Ti peaks did not match $\mathrm{C}_{\text {peaks }}$ (at 5950, 5670, 5080, 4905, and $4850 \mathrm{cal} \mathrm{BP}$ ).

To test the short-term impact of local fire events on vegetation, interactions between vegetation and biomass burning rates were analysed using cross-correlations (Supplementary Material). Cross-correlograms between the fire-intolerant Abies alba Mill. and charcoal-accumulation rates showed significant negative correlations at time lags around lag 0 consistently with the known fire sensitivity of this conifer (Tinner et al., 1999). Taxa favoured by biomass burning (i.e., with cross-correlograms showing significant positive correlations at lags around lag 0 ) were the lightdemanding mesic trees Fraxinus, Quercus, and Ulmus. These results support the hypothesis that increased biomass burning rates influenced short-term vegetation shifts with decreases in the fire-sensitive conifer (Abies) and increases in less flammable deciduous trees. Fagus was positively correlated at lag +4 , thus after about 60 years following increased biomass burning.

\section{Influence of environmental changes on pigment concentrations and diatom assemblages}

Ordination analyses of the diatom dataset by RDA (Fig. 5) identified Aphanizophyll $\left(\mathrm{N}_{2}\right.$-fixing planktonic cyanobacteria), Myxoxanthophyll (colonial attached cyanobacteria), S, and $\mathrm{Si}$ as the subset of variables that explained significant and independent amounts of variation. These four variables explained a large proportion $(65 \%)$ of the variance in the diatom assemblages $\left(\lambda_{1}=0.63\right.$; $\lambda_{2}=0.02$ ). RDA axis 1 captured an $\mathrm{N}_{2}$-limitation gradient (indicated by the abundance of Aphanizophyll) that is positively correlated with $\mathrm{S}$ and negatively correlated with $\mathrm{Si}$. The latter variable is likely indicative of diatom-phytoplankton abundance since the $\mathrm{Si}$ and the diatom-accumulation rate records show similar trends (Fig. 3 A,B).

\section{DISCUSSION}

Empirical models suggest that thermally stratified lakes can undergo rapid ecosystem changes and that, as opposed to shallow lakes, macrophytes do not play a relevant role in regulating ecosystem dynamics (GenkaiKato and Carpenter, 2005). Several studies clearly showed the strong influence of external nutrient loading due to catchment disturbances such as the creation of cul-

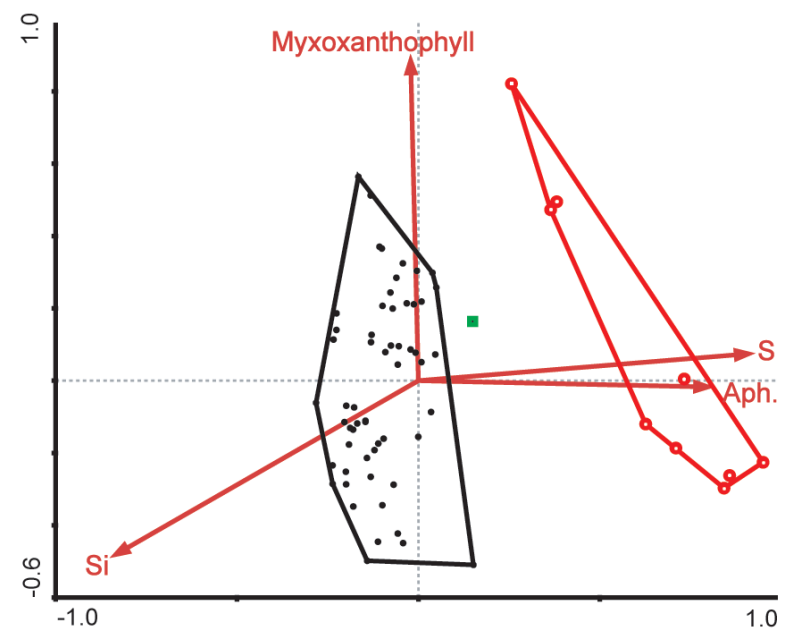

Fig. 5. RDA ordination of diatom assemblages from Lago Grande di Avigliana, showing sample scores (symbols) and environmental variables [Myxoxanthophyll, Silicate (Si), Sulphur (S), and Aphanizophyll (Aph.)] determined by forward selection (vectors). Samples deposited prior to $4915 \mathrm{cal} \mathrm{BP}$ (full circles) and samples deposited after 4915 cal BP (empty circles) are encircled by envelopes. 
tural land to yield crops and grazing meadows (Fritz, 1989; Dearing et al., 2006) on organic carbon concentrations in the sediments (Lotter et al., 1997b; Dean, 2002; Marchetto et al., 2004). Similarly, major land-cover changes at times of high-amplitude climatic changes (such as at the Younger Dryas/Holocene boundary, $\sim 11,650$ cal BP) have been invoked as major drivers for aquatic ecosystem dynamics (Brauer et al., 1999; Schmidt et al., 2002). However, other studies suggest that nutrient concentrations in the photic zone can also change in response to lower-amplitude climate changes that may influence mixing regime or mixing depth (Smol and Boucherle, 1985; Kirilova et al., 2009; Martin-Puertas et al., 2012). The high-resolution multi-proxy record from Lago Grande di Avigliana may contribute to further our understanding of the influence of Holocene climate variability on stratified lakes.

The lake sediments were deposited at a complex time when climate was changing and agriculture was just beginning in the region. During the end-stages of the Neolithic, settlements probably had short duration and shifting-cultivation agriculture, possibly with the use of fire, was widespread in Central Europe (Rösch et al., 2002). In the Avigliana region no direct evidence for local settlements older than the pile dwellings dating to the Middle-Late Bronze Age (i.e., about 3500 to 2800 cal BP) (Volta, 1955; De Marinis, 1998) has been found. However, absence of evidence for archaeological settlements cannot be used as a proof of the local absence of people. In fact, settlements in the nearby valley during, for example, the Copper Age (Venturino Gambari, 1998) attest to the presence of small farming groups about 4600 to 4200 cal BP (Finsinger and Tinner, 2006). Moreover, an earlier investigation of the sediments from the nearby Lago Piccolo di Avigliana suggested that the combined effects of climatic change towards cooler conditions and human activities likely contributed to land-cover changes involving the expansion of shade-tolerant and drought-sensitive Fagus populations (Valsecchi et al., 2008).

Cross-correlations between charcoal-accumulation rates and anthropogenic-indicator pollen are, however, not conclusive concerning the use of fire for agriculture because Cerealia-type pollen is positively correlated at time lag +3 (i.e., $\sim 45$ years after a biomass burning event) instead of increasing immediately after biomass burning events. It may be speculated that biomass burning preceded cereal cultivations and that the area of croplands increased for $\sim 40$ years. This would be consistent with evidence from analyses in southern Germany (Bogaard, 2002). Still, cross-correlations suggest short-term vegetation responses to increased fire activity and it is likely that the actual landscape openness was larger than estimated by pollen percentages (Soepboer et al., 2010). Nevertheless, the overall forest-cover changes in the region as es- timated by pollen percentages alone were small and do not compare to major land-cover changes as recorded during the earlier Younger Dryas/Holocene transition or at the onset of intensive agriculture during the later Bronze and Iron Ages in Central Europe, when a distinct link between forest cover, intensive agriculture, and enhanced nutrient flux from external sources into lakes could be made (Fritz, 1989; Brauer et al., 1999; Schmidt et al., 2002; Bradshaw et al., 2005).

In addition to agriculture, natural fire occurrence or man-made fires may also cause an increase in nutrients due to erosion of nutrient-rich topsoil (Wright, 1976; Hickman et al., 1990; Kelly et al., 2006). Peaks of charcoal-accumulation rates in lake sediments can lag a fire event by up to 15-30 years (Whitlock and Millspaugh, 1996; Duffin et al., 2008; Higuera et al., 2011). Accepting such a lag, the comparison between Ti and charcoal records suggests that some fire events may have led to short-term increases of soil erosion from the catchment. However, several Ti peaks were unrelated to large charcoal peaks, perhaps because local fire episodes were smaller in size or because processes independent of biomass burning (e.g., strong precipitation events) could have enhanced erosion. Nevertheless, as indicated by the $\mathrm{Ti}$ record, erosion from the catchment was highest at around $6100 \mathrm{cal} \mathrm{BP}$ and the frequency of Ti peaks was lower after about 5400 cal BP. Overall, it seems that although land cover changed slightly between 6200 and 4800 cal BP, nutrient input from topsoil erosion was probably not enhanced. This is consistent with results from the $\mathrm{C}: \mathrm{N}$ ratio record pointing to a continuous input of terrestrial organic matter into the lake (Meyers, 1994) as well as with results of the RDA, which indicated that variables characterizing processes in the terrestrial ecosystem did not explain significant amounts of variance in the diatom assemblages.

It is certainly difficult to accurately assess the lead-lag effects due to large uncertainties in the chronologies of the paleoclimate proxy records and of the Lago Grande di Avigliana record. In fact, a first change in mixing regime is recorded by pigments of obligate sulphur bacteria at $\sim 5400 \mathrm{cal}$ BP. Obligate anaerobic photosynthetic sulphur bacteria are restricted to anoxic conditions in the presence of sulphides and are capable of photosynthesis at extremely low irradiances of light (Lampert and Sommer, 1999). Instead, green sulphur bacteria (isorenieratene) are able to live at greater depths than purple sulphur bacteria (okenone) because they can use lower light intensities (Lampert and Sommer 1999). As isorenieratene and okenone are characterized by similar degrees of chemical stability (Leavitt and Hodgson, 2001), the absence of okenone and the persistence of isorenieratene starting from $\sim 5400 \mathrm{cal} \mathrm{BP}$ attests to a stronger and deeper mixing of the upper water column. Such a change could have caused nutrients stored in the anoxic hypolimnion to 
be periodically returned to the epilimnion during times of deeper mixing in spring. In keeping with this, pigment concentrations of Lutein (green algae), Alloxanthin, Echinenone, and Zeaxanthin (cyanobacteria), and of $\beta$ Carotene (all primary producers), increased from $\sim 5400$ cal BP onwards pointing towards enhanced primary productivity. The increase of Aphanizophyll (from $\mathrm{N}_{2}$-fixing cyanobacteria) may attest to the occurrence of $\mathrm{N}_{2}$-limitation at the end of the growing season in the epilimnion as a consequence of enhanced summer phytoplankton production. However, the amount of nutrients brought into the epilimnion was probably small because diatom assemblages were still stable between 5400 and $4900 \mathrm{cal} \mathrm{BP}$. In addition, the change in mixing regime probably did not affect the deeper water column at that time, as the Fe:Mn ratio, which is often used to support the evidence of anoxia at the sediment-water interface because the solubility of $\mathrm{Mn}$ increases more than solubility of Fe under strongly reducing conditions (Engstrom and Wright, 1984), remained largely unchanged. Several proxy records from the northern Mediterranean borderlands suggest that the climate shifted towards wetter/cooler conditions around 5000-4500 cal BP (Magny et al., 2013). The Fagus population expansion has been attributed to a combined effect of a climate shift (cold phase CE-6 ( $\sim 5400$ $4900 \mathrm{cal}$ BP); Haas et al., 1998) and of human activities (Tinner and Lotter, 2006; Valsecchi et al., 2008). Moreover, lake-level change records from lakes located further south (Lago dell'Accesa, central Italy, Magny et al., 2007) and further north (Lac Cerin, Jura Mountains, Magny et al., 2011) also indicate a significant shift towards higher lake levels at $\sim 5000-4500$ cal BP around the Alpine region. In addition, fire activity strongly decreased around $5000 \mathrm{cal}$ BP likely as a result of cooler/wetter summers (Vanniere et al., 2011).

The broad coincidence between the phytoplankton dynamics and rising lake-levels and cooler temperatures may, point to the effects of climate change on the nutrient recycling in the lake by means of the control that climate can exert on mixing depth. Several lines of evidence point to increased productivity after $\sim 4900 \mathrm{cal}$ yr BP at Lago Grande di Avigliana. Diatom-assemblage shifts similar to those of Lago Grande di Avigliana have been related to increased nutrient flux to the epilimnion due to a change in mixing regime (Moser et al., 2002; Kirilova et al., 2009). Smol and Boucherle (1985), for example, suggested that in strongly stratified lakes the breakdown of water-column stratification may cause nutrients stored in the hypolimnion to be returned to the epilimnion, allowing hypertrophic diatoms such as Stephanodiscus Ehrenberg and Fragilaria to replace oligotrophic planktonic taxa such as Cyclotella as reconstructed in the sediments of Lago Grande di Avigliana. S. alpinus are cold-water preferring early-spring phytoplanktonic bloomers that require rela- tively high phosphorus values as often occurs during spring mixing (Lotter, 1989; Kirilova et al., 2008). In keeping with this, the higher relative abundance of small Fragilariaceae and benthic diatoms may attest to higher turbidity (Bigler et al., 2003) and the simultaneous increase of Chrysophycean cysts also points towards enhanced primary productivity in the water column (Bradbury and Dieterich-Rorup, 1993). The enhanced primary productivity during spring and summer possibly led to lower Si:P ratio due to depleted Si supply (Lotter, 2001) and favoured a shift towards other planktonic algal groups (e.g., green algae, cyanobacteria) during the summer stagnation as shown by increasing concentrations of Chlorophyll b, Lutein, and Diadinoxanthin. Further, pigments from cyanobacteria showed first an increase of colonial cyanobacteria (Myxoxanthophyll) followed by an increase of $\mathrm{N}_{2}$-fixing cyanobacteria (Aphanizophyll), probably in response to decreasing P:N ratios and stagnation over the course of the summer, making the cyanobacteria more competitive in comparison to diatoms.

In addition to showing that nutrients were returned to the epilimnion from the hypolimnion as suggested by previous studies (Smol and Boucherle, 1985; Martin-Puertas et al., 2012), the geochemical record suggests that P-release rates from the sediments could also have increased, thereby accelerating eutrophication by internal loading. In fact, enhanced precipitation of iron sulphides (FeS) together with higher accumulation rates of organic matter at the sediment-water interface may enhance P-release rates, as they are strongly influenced by the balance between gross sedimentation of organic matter, $\mathrm{P}, \mathrm{Fe}$, and the sulphide production driven by diagenetic processes in the sediment (Gächter and Müller, 2003). The stability of this feedback mechanism is still unclear in the absence of additional case studies that allow consideration of possibly non-linear relationships between a variable and multiple predictors. However, because all these factors act in the same direction, i.e., increased eutrophication, it is probable that the changes observed in the diatom assemblages were caused both by mixing-depth changes bringing nutrients into the epilimnion and by P-release rates from the sediments.

\section{CONCLUSIONS}

Our methodology of multi-proxy investigation of sediments seems well adapted to documenting long-term lake-ecosystem dynamics with an integrative approach of catchment dynamics (land-cover changes, runoff, fire history) and within-lake processes (mixing depth, P-release rates, phytoplankton dynamics) in strongly stratified lakes. Such lakes with long sequences of varved sediments have been reported from throughout the world from mid-latitudes to the inner tropics, thus covering a wide range of climatic conditions. Multiple-site investigations 
could allow a better assessment of the respective roles of factors influencing the long-term dynamics of stratified lakes. Moreover, a record spanning a longer time frame might be necessary to get an insight into the response to different intensities of land-cover changes and thus bring more convincing evidence as to the mechanisms leading to rapid shifts in such aquatic ecosystems.

\section{ACKNOWLEDGMENTS}

We are thankful to H. Cremer, T. van Druten, O. Heiri, S. Musazzi, and V. Valsecchi for help during fieldwork, to D. Colombaroli, J.M. van Aken, E. Vescovi, F. Zeugin, A. Zwyssig and M. Sturm for help during subsampling of the sediment cores, to $\mathrm{V}$. Wennrich for assistance during the XRF analyses, and to S. Subitani for macrocharcoal analysis. Thoughtful and encouraging suggestions from S. Brooks, M. Brenner, and from two anonymous reviewers helped to improve the manuscript.

This study was financially supported by the CRUS (33-938) and by the Swiss National Science Foundation (SNF) (PBBE2-108573).

\section{REFERENCES}

Battarbee RW, 1973. A new method for estimation of absolute microfossil numbers, with reference especially to diatoms. Limnol. Oceanogr. 18:647-653.

Battarbee RW, Bennion H, 2011. Palaeolimnology and its developing role in assessing the history and extent of human impact on lake ecosystems. J. Paleolimn. 45:399-404.

Behre KE, 1981. The interpretation of anthropogenic indicators in pollen diagrams. Pollen Spores 23:225-245.

Bennett KD, 1996. Determination of the number of zones in a biostratigraphical sequence. New Phytol. 132:155-170.

De Bernardi R, Giussani G, Mosello R, Origgi I, 1984. [Quadro limnologico di cinque piccoli laghi piemontesi (Avigliana, Trana, Candia, Viverone, Sirio)].[Article in Italian]. Doc. Ist. Ital. Idrobiol. 5:97.

Bigler C, Grahn E, Larocque I, Jeziorski A, Hall R,. 2003. Holocene environmental change at Lake Njulla (999 m asl), northern Sweden: a comparison with four small nearby lakes alongan altitudinal gradient. J. Paleolimn. 29:13-29.

Bogaard A, 2002. Questioning the relevance of shifting cultivation to Neolithic farming in the loess belt of Europe: evidence from the Hambach Forest experiment. Veg. Hist. Archaeobot. 11:155-168.

Ter Braak CJF, Šmilauer P, 2003. CANOCO reference manual and user's guide to CANOCO for Windows, ver. 4. Centre for Biometry Wageningen, The Netherlands.

Bradbury JP, Dieterich-Rorup KV, 1993. Holocene diatom paleolimnology of Elk Lake, Minnesota. Geol. Soc. Am. 276:215-237.

Bradshaw EG, Rasmussen P, Nielsen H, Anderson NJ, 2005. Mid- to late-Holocene land-use change and lake development at Dallund So, Denmark: trends in lake primary production as reflected by algal and macrophyte remains. Holocene 15:1130-1142.

Brauer A, Endres C, Günter C, Litt T, Stebich M, Negendank
JFW, 1999. High resolution sediment and vegetation responses to Younger Dryas climate change in varved lake sediments from Meerfelder Maar, Germany. Quat. Sci. Rev. 18:321-329.

Croudace IW, Rindby A, Rothwell R, 2006. ITRAX: description and evaluation of a new multi-function X-ray core scanner, p. 51-63. In: R.G. Rothwell (ed.), New techniques in sediment core analysis. The Geological Society of London.

Dean W, 2002. A 1500-year record of climatic and environmental change in Elk Lake, Clearwater County, Minnesota II: geochemistry, mineralogy, and stable isotopes. J. Paleolimn. 27:301-319.

Dearing J, 2008. Landscape change and resilience theory: a palaeoenvironmental assessment from Yunnan, SW China. Holocene 18:117-127.

Dearing JA, Battarbee RW, Dikau R, Larocque I, Oldfield F, 2006. Human-environment interactions: Learning from the past. Reg. Env. Change 6:1-16.

De Marinis R, 1998. [La metallurgia dell'antica e media età del Bronzo in Piemonte, p. 157-186]. In: L. Mercando and M. Venturino Gambari (eds.) [Archeologia in Piemonte].[Book in Italian]. La Preistoria, Torino, Italy.

Duffin KI, Gillson L, Willis KJ, 2008. Testing the sensitivity of charcoal as an indicator of fire events in savanna environments: quantitative predictions of fire proximity, area and intensity. Holocene 18:279.

Engstrom DR, Wright HEJ, 1984. Chemical stratigraphy of lake sediments as a record of environmental change, p. 1167. In: E.Y. Haworth and J.W. Lund (eds.), Lake sediments and environmental history studies in palaeolimnology and palaeoecology in honour of Winifred Tutin. University of Minnesota Press.

Finsinger W, Bigler C, Krähenbühl U, Lotter AF, Ammann B, 2006. Human impact and eutrophication patterns during the past $\sim 200$ yrs at Lago Grande di Avigliana (N. Italy). J. Paleolimn. 36:55-67.

Finsinger W, Tinner W, 2006. Holocene vegetation and landuse changes in the forelands of the southwestern Alps, Italy. J. Quat. Sci. 21:243-258.

Finsinger W, Tinner W, van der Knaap W, Ammann B, 2006. The expansion of hazel (Corylus avellana L.) in the southern Alps: a key for understanding its early Holocene history in Europe? Quat. Sci. Rev. 25:612-631.

Folke C, Carpenter S, Walker B, Scheffer M, Elmqvist T, Gunderson L, Holling CS, . 2004. Regime shifts, resilience, and biodiversity in ecosystem management. Ann. Rev. Ecol. Evol. Syst. 35:557-581.

Fritz SC. 1989. Lake development and limnological response to prehistoric and historic land-use in Diss, Norfolk, UK. J. Ecol. 77:182-202.

Gächter R, Müller B, 2003. Why the phosphorus retention of lakes does not necessarily depend on the oxygen supply to their sediment surface. Limnol. Oceanogr. 48:929-933.

Genkai-Kato M, 2007. Regime shifts: catastrophic responses of ecosystems to human impacts. Ecol. Res. 22:214-219.

Genkai-Kato M, Carpenter SR,. 2005. Eutrophication due to phosphorous recycling in relation to lake morphometry, temperature, and macrophytes. Ecology 86:210-219.

Genries A, Finsinger W, Asnong H, Bergeron Y, Carcaillet C, 
Garneau M, Hély C, Ali AA, 2012. Local versus regional processes: can soil characteristics overcome climate and fire regimes by modifying vegetation trajectories? J. Quat. Sci. 27:745-756.

Guilizzoni P, Lami A, Marchetto A, 1992. Plant pigment ratios from lake sediments as indicators of recent acidification in alpine lakes. Limnol. Oceanogr. 37:1565-1569.

Haas JN, Richoz I, Tinner W, Wick L, 1998. Synchronous Holocene climatic oscillations recorded on the Swiss Plateau and at timberline in the Alps. Holocene 8:301-309.

Heiri O, Lotter AF, Lemcke G, 2001. Loss on ignition as a method for estimating organic and carbonate content in sediments: reproducibility and comparability of results. J. Paleolimn. 25:101-110.

Hickman M, Schweger CE, Klarer DM, 1990. Baptiste Lake, Alberta - A late Holocene history of changes in a lake and its catchment in the southern Boreal forest. J. Paleolimn. 4:253-267.

Higuera PE, Brubaker LB, Anderson PM, Hu FS, Brown TA, 2009. Vegetation mediated the impacts of postglacial climate change on fire regimes in the south-central Brooks Range, Alaska. Ecol. Monogr. 79:201-219.

Higuera PE, Peters ME, Brubaker LB, Gavin DG, 2007. Understanding the origin and analysis of sediment-charcoal records with a simulation model. Quat. Sci. Rev. 26:1790-1809.

Higuera PE, Whitlock C, Gage JA, 2011. Linking tree-ring and sediment-charcoal records to reconstruct fire occurrence and area burned in subalpine forests of Yellowstone National Park, USA. Holocene 21:327-341.

Jump AS, Hunt JM, Penuelas J. 2006. Rapid climate change-related growth decline at the southern range edge of Fagus sylvatica. Global Change Biology. 12:2163-2174.

Juggins, S, 2012. rioja: analysis of Quaternary Science Data, R package version (0.8-5). Available from: http://cran.r-project.org/package $=$ rioja

Kelly EN, Schindler DW, Louis VLS, Donald DB, Vladicka KE, 2006. Forest fire increases mercury accumulation by fishes via food web restructuring and increased mercury inputs. P. Natl. Acad. Sci. USA 103:19380-19385.

Kirilova E, Heiri O, Enters D, Cremer H, Lotter AF, Zolitschka B, Hübener T, 2009. Climate-induced changes in the trophic status of a Central European lake. J. Limnol. 68:71-82.

Kirilova EP, Bluszcz P, Heiri O, Cremer H, Ohlendorf C, Lotter AF, Zolitschka B, 2008. Seasonal and interannual dynamics of diatom assemblages in Sacrower See (NE Germany): a sediment trap study. Hydrobiologia 614:159-170.

Krammer K, Lange-Bertalot H, 1999a. [Bacillariophyceae. 1. Teil: Naviculaceae]. In: [Süßwasserflora von Mitteleuropa, Band 2/1].[Book in German]. Gustav Fischer Verlag, Stuttgart.

Krammer K, Lange-Bertalot H, 1999b. [Bacillariophyceae. 2. Teil: Bacillariaceae, Epithemiaceae, Surirellaceae]. In: [Süßwasserflora von Mitteleuropa, Band 2/2: BacillariophyceaeBacillariaceae, Epithemiaceae, Surirellaceae].[Book in German]. Gustav Fischer Verlag, Stuttgart.

Krammer K, Lange-Bertalot H, 2000. [Bacillariophyceae. 3. Teil: Centrales, Fragilariaceae, Eunotiaceae]. In: [Süßwasserflora von Mitteleuropa, Band 2/3].[Book in German]. Gustav Fischer Verlag, Stuttgart.

Krammer K, Lange-Bertalot H, 2004. [Bacillariophyceae. 4. Teil: Achnanthaceae. Kritische Ergänzungen zu Achnanthes s.1., Navicula s.str., Gomphonema]. In: [Süßwasserflora von Mitteleuropa, Band 2/3].[Book in German]. Gustav Fischer Verlag, Stuttgart.

Lami A, Guilizzoni P, Marchetto A, 2000. High resolution analysis of fossil pigments, carbon, nitrogen and sulphur in the sediments of eight European Alpine lakes: the MOLAR project. J. Limnol. 59:15-28.

Lampert W, Sommer U, 1999. [Limnoökologie]. Thieme, Stuttgart: 489 pp.

Leavitt PR, Hodgson DA. 2001. Sedimentary pigments, p. 295325. In: J.P. Smol, H.J. Birks and W.M. Last (eds.), Tracking environmental change using lake sediments: terrestrial, algal, and siliceous indicators. Kluwer Academic Publishers.

Lotter AF, 1989. Evidence of annual layering in Holocene sediments of Soppensee, Switzerland. Aquat. Sci. 51:19-30.

Lotter AF, 2001. The palaeolimnology of Soppensee (Central Switzerland), as evidenced by diatom, pollen, and fossil-pigment analyses. J. Paleolimn. 25:65-79.

Lotter AF, Birks HJB, 1997. The separation of the influence of nutrients and climate on the varve time-series of Baldeggersee, Switzerland. Aquat. Sci. 59:362-375.

Lotter AF, Birks HJB, Hofmann W, Marchetto A, 1997a. Modern diatom, cladocera, chironomid and chrysophyte cyst assemblages as quantitative indicators for the reconstructions of past environmental conditions in the Alps I. Climate. J. Paleolimn. 18:395-420.

Lotter AF, Lemcke G, 1999. Methods for preparing and counting biochemical varves. Boreas 28: 243-252.

Lotter AF, Sturm M, Teranes JL, Wehrli B, 1997b. Varve formation since 1885 and high-resolution varve analyses in hypertrophic Baldeggersee (Switzerland). Aquat. Sci. 59:304-325.

Magny M, de Beaulieu J-L, Drescher-Schneider R, Vannière B, Walter-Simonnet A-V, Miras Y, Millet L, Bossuet G, Peyron O, Brugiapaglia E, Leroux A, 2007. Holocene climate changes in the central Mediterranean as recorded by lakelevel fluctuations at Lake Accesa (Tuscany, Italy). Quat. Sci. Rev. 26:1736-1758.

Magny M, Bossuet G, Ruffaldi P, Leroux A, Mouthon J, 2011. Orbital imprint on Holocene palaeohydrological variations in west-central Europe as reflected by lake-level changes at Cerin (Jura Mountains, eastern France). J. Quat. Sci. 26: 171-177.

Magny M, Combourieu-Nebout N, de Beaulieu JL, Bout-Roumazeilles V, Colombaroli D, Desprat S, Francke A, Joannin S, Peyron O, Revel M, Sadori L, Siani G, Sicre MA, Samartin S, Simonneau A, Tinner W, Vannière B, Wagner B, Zanchetta G, Anselmetti F, Brugiapaglia E, Chapron E, Debret M, Desmet M, Didier J, Essallami L, Galop D, Gilli A, Haas JN, Kallel N, Millet L, Stock A, Turon JL, Wirth S, 2013. North-south palaeohydrological contrasts in the central Mediterranean during the Holocene: tentative synthesis and working hypotheses. Clim. Past 9:2043-2071.

Mantoura RFC, Llewellyn CA, 1983. The rapid determination of algal chlorophyll and carotenoid pigments and their breakdown products in natural waters by reversed-phase high-performance liquid chromatography. Anal. Chim. Acta 151:297-314.

Marchetto A, Lami A, Musazzi S, Massaferro J, Langone L, Guilizzoni P, 2004. Lake Maggiore (N. Italy) trophic his- 
tory: fossil diatom, plant pigments, and chironomids, and comparison with long-term limnological data. Quat. Int. 113:97-110.

Martin-Puertas C, Matthes K, Brauer A, Muscheler R, Hansen F, Petrick C, Aldahan A, Possnert G, van Geel B, 2012. Regional atmospheric circulation shifts induced by a grand solar minimum. Nat. Geosci. 5:397-401.

Meyers P,. 1994. Preservation of elemental and isotopic source identification of sedimentary organic matter. Chem. Geol. 114:289-302.

Moser KA, Smol JP, MacDonald GM, Larsen CPS, 2002. 19th century eutrophication of a remote boreal lake: a consequence of climate warming? J. Paleolimn. 28:269-281.

Rösch M, Ehrmann O, Herrmann L, Schulz E, Bogenrieder A, Goldammer JP, Hall M, Page H, Schier W, 2002. An experimental approach to Neolithic shifting cultivation. Veget. Hist. Archaeobot. 11:143-154.

Scheffer M, Carpenter SR, 2003. Catastrophic regime shifts in ecosystems: linking theory to observations. Trends Ecol. Evol. 18:648-656.

Schmidt R, Psenner R, Müller J, Indinger P, Kamenik C, 2002. Impact of late glacial climate variations on stratification and trophic state of the meromictic Lake Längsee (Austria): validation of a conceptual model by multi proxy studies. J. Limnol. 61:49-60.

Segerström U, Renberg I. 1986. Calculating net annual accumulation rates of sediment components exemplified by pollen. Hydrobiologia 143:45-47.

Smol JP, 2008. Pollution of lakes and rivers: a paleoenvironmental perspective. Blackwell Publ.: 383 pp.

Smol JP, Boucherle MM, 1985. Postglacial changes in algal and cladoceran assemblages in Little Round Lake, Ontario. Arch. Hydrobiol. 103:25-49.

Smol JP, Wolfe AP, Birks HJB, Douglas MSV, Jones VJ, Korhola A, Pienitz R, Rühland K, Sorvari S, Antoniades D, 2005. Climate-driven regime shifts in the biological communities of arctic lakes. P. Natl. Acad. Sci. USA 102: 4397-4402.

Soepboer W, Sugita S, Lotter AF, 2010. Regional vegetationcover changes on the Swiss Plateau during the past two millennia: A pollen-based reconstruction using the REVEALS model. Quat. Sci. Rev. 29:472-483.
Stockmarr J,. 1971. Tablets with spores used in absolute Pollen Analysis. Pollen Spores 13:615-621.

Tartari G, Buraschi E, Monguzzi C, Marchetto A, Copetti D, Salerno F, Previtali L, Tatti S, Barbero G, Pagnotta R, 2004. [Progetto LIMNO: qualità delle acque lacustri italiane. Vol 1. Sintesi dei risultati].[Book in Italian]. Quaderni IRSA: $339 \mathrm{pp}$.

Tinner W, Hubschmid P, Wehrli M, Ammann B, Conedera M, 1999. Long-term forest fire ecology and dynamics in southern Switzerland. J. Ecol. 87:273-289.

Tinner W, Lotter AF, 2006. Holocene expansions of Fagus silvatica and Abies alba in Central Europe: where are we after eight decades of debate? Quat. Sci. Rev. 25:526-549.

Valsecchi V, Finsinger W, Tinner W, Ammann B, 2008. Testing the influence of climate, human impact, and fire on the Holocene population expansions of Fagus sylvatica in the southern Prealps (Italy). Holocene 18:603-614.

Vanniere B, Power MJ, Roberts N, Tinner W, Carrion J, Magny M, Bartlein P, Colombaroli D, Daniau AL, Finsinger W, GilRomera G, Kaltenrieder P, Pini R, Sadori L, Turner R, Valsecchi V, Vescovi E, 2011. Circum-Mediterranean fire activity and climate changes during the mid-Holocene environmental transition (8500-2500 cal. BP). Holocene 21:53-73.

Venturino Gambari M, 1998. [Forme e dinamiche degli insediamenti umani nel Neolitoco e nell'Eneolitico, p. 101122]. In: L. Mercando and M. Venturino Gambari (eds.) [Archeologia in Piemonte].[Book in Italian]. La Preistoria, Torino, Italy.

Volta R, 1955. [Le stazioni palafitticole di Avigliana e di Trana].[Article in Italian]. Sibrium 2:213-224.

Whitlock C, Millspaugh SH, 1996. Testing the assumption of fire-history studies: an examination of modern charcoal accumulation in Yellowstone National Park, USA. Holocene 6:7-15.

Willis KJ, Bailey RM, Bhagwat SA, Birks HJB, 2010. Biodiversity baselines, thresholds and resilience: testing predictions and assumptions using palaeoecological data. Trends Ecol. Evol. 25:583-591.

Wright RF, 1976. The impact of forest fire on the nutrient influxes to small lakes in northeastern Minnesota. Ecology 57:649-663. 